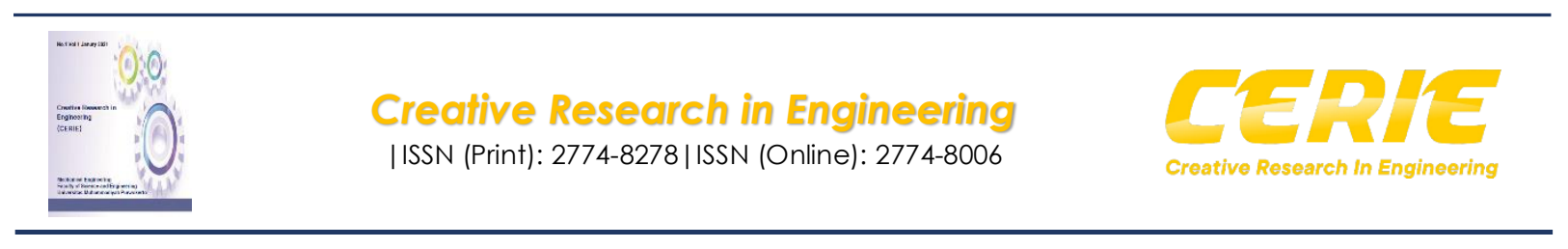

Research Article

\title{
Studi Numerik dan Eksperimen Aerodinamika Airfoil NACA 24112
}

Dhedhek Wahyu Aji Perdana ${ }^{1}$ dan Marwan Effendy ${ }^{2}$

${ }^{1,2}$ Teknik Mesin, Fakultas Teknik, Universitas Muhammadiyah Surakarta, Indonesia

Email: Dhedhekwahyuaji@gmail.com, Marwan.effendy@ums.ac.id

Corespondensi author: Marwan.effendy@ums.ac.id

Article History:

Online first:

18 January 2021

Keywords: Airfoil, NACA 24112, Wind Tunnel

Kata Kunci: Airfoil, NACA 24112, Terowongan Angin
ABSTRACT

This study aims to investigate experimentally and numerically the characteristics of the NACA 24112 airfoil. This study focuses on investigations of lift coefficient $\left(C_{L}\right)$, drag coefficient $(C D)$, and $C_{L} / C_{D}$ ratio and pressure, including flow visualisation around the airfoil. The study was conducted at an angle of attack ranging to $-15^{\circ}-20^{\circ}$ and various Mach number at 0.0728 and 0.0809. The experimental test used a test specimen with a span dimension of 20 $\mathrm{cm}$ and a chord of $10 \mathrm{~cm}$ with an open wind tunnel. A total of 376,500 square elements with values $\Delta y+$ to 9.6 were successfully generated to achieve the accuracy of the simulation. The results showed that the $C_{L}$ and $C_{D}$ values obtained from the experimental and simulation results showed a similar trend. The $C_{D}$ value of the experimental results is greater than the simulation results. The $C_{L}$ and $C_{D}$ values will increase with increasing flow velocity and increasing the angle of attack. A stall occurs at an attack angle of $20^{\circ}$.

\section{ABSTRAK}

Penelitian ini bertujuan untuk mengetahui karakteristik Airfoil NACA 24112 secara eksperimental dan numerik. Penelitian ini berfokus pada investigasi koefisien lift $\left(C_{L}\right)$, koefisien drag $\left(C_{D}\right)$, rasio $C_{L} / C_{D}$, tekanan dan visualisasi aliran di sekitar airfoil. Penelitian dilakukan pada sudut serang berkisar $-15^{\circ}-20^{\circ}$ dan berbagai angka Mach pada 0,0728 dan 0,0809. Pengujian eksperimental menggunakan benda uji dengan span $20 \mathrm{~cm}$ dan chord $10 \mathrm{~cm}$ dengan wind tunnel jenis terbuka. Sebanyak 376.500 elemen bujur sangkar dengan nilai $\Delta y+$ hingga 9,6 berhasil dibangkitkan untuk mencapai akurasi simulasi.Hasil penelitian menunjukkan bahwa nilai $C_{L}$ dan $C_{D}$ yang diperoleh dari hasil eksperimen dan simulasi menunjukkan trend yang mirip. Nilai CD hasil eksperimen lebih besar dari hasil simulasi. Nilai CL dan CD akan semakin naik 
Vol.1, No.1, Januari 2021, pp.1-11

e-ISSN: 2774-8006 | p-ISSN: 2774-8278

seiring dengan meningkatnya kecepatan aliran dan bertambah besarnya sudut serang. Stall terjadi pada sudut serang $20^{\circ}$.

\section{PENDAHULUAN}

Riset yang mengacu pada pengembangan teknologi aerodinamika sangat berkembang pesat yaitu airfoil sebagai salah satu bagian penting dalam dunia aerodinamika telah banyak dilakukan pada tahun-tahun belakangan ini. Hasil dari berbagai eksperimen telah banyak digunakan untuk mendesain airfoil dalam berbagai konfigurasi sayap pesawat yang sesuai dengan penggunaanya. Airfoil sebagai luasan yang ditempatkan dalam aliran udara untuk menghasilkan gaya aerodinamika yang efisien, ketika udara bergerak melalui airfoil udara tersebut terbelah dan melewati permukaan airfoil dan berfungsi sebagai model bentuk untuk mendapatkan gaya angkat dan gaya hambat[1].

Perubahan sudut serang airfoil memainkan peran sangat penting terhadap karakteristik aerodinamika aliran, seperti koefisien lift, koefisien drag, rasio lift-drag(L/D), koefisien tekanan dan profil aliran[2]. Pada kecepatan yang tetap gaya angkat akan meningkat seiring dengan peningkatan sudut serang hingga mencapai nilai maksimumnya dan kemudian tiba tiba turun, fenomena ini disebut stalling [1]. Metode eksperimen dengan terowongan angin (Wind Tunnel) dimana kondisi aliran mempengaruhi kinerja model airfoil [4], model uji ditempatkan pada force balancing dengan dimensi ruang $60 \mathrm{~cm}$ (panjang) x $32 \mathrm{~cm}$ (lebar) x $30 \mathrm{~cm}$ (tinggi). Parameter aliran yang berkaitan dengan mach number dan reynolds number [5] sesuai dengan keadaan sebenarnya, penelitian ini menggunakan wind tunnel karena mudah penggunaanya dan didapatka gaya lift dan drag secara langsung ketika pengujian [6]Selain dengan metode eksperimen wind tunnel juga dapat dianalisa dan divalidasi menggunakan software berbasis computational fluid dynamic [7] model uji airfoil 2D menggunakan mesh terstruktur dan model turbulensi sparat almarast [8].

Metode numerik yang dijelaskan diuji pada beberapa masalah patokan dan perbandingan dengan data referensi yang tersedia, disajikan dalam penerapan metode untuk solusi dari masalah Aerodinamik [9]. Hasil dari simulasi dalam penelitian ini berupa kontur sebaran tekanan di sekeliling airfoil dan kontur sebaran kecepatan fluida yang mengalir di sekeliling airfoil. Dan juga dapat dilihat gaya-gaya yang terjadi pada airfoil sehingga dapat dihitung nilai $\mathrm{C}_{\mathrm{L}}$ dan $C_{D}$ [10] Penelitian ini bertujuan untuk mengetahui karakteristik aerodinamis airfoil naca 24112 dengan melakukan pengujian wind tunnel subsonic dan dengan analisa numerik computational fluid dynamic (CFD) dengan memvariasikan sudut serang $-20^{\circ}$ sampai $15^{\circ}$, dan variasi angka Mach 0.0728 dan 0.0809 dengan span $200 \mathrm{~cm}$ airfoil asimetris reflex.

\section{METODE PENELITIAN}

Penelitian ini dilakukan dengan 2 cara untuk mengevaluasi karakteristik aerodinamika Airfoil Naca 24112 yaitu dengan metode eksperimen dan simulasi CFD(Computational Fluid Dynamic). Dari kedua metode menggunkan geometry spesimen yang serupa dengan dimensi yang berbdeda, 3D untuk eksperimen dan 2D untuk permodelan simulasi. 


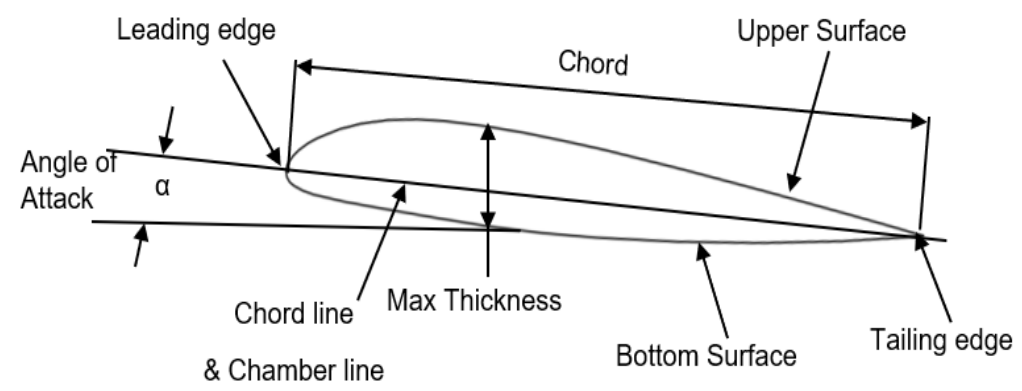

Gambar 1. Spesimen uji

\section{Eksperimen}

Spesimen uji Naca 24112 dibuat dengan 3D Printer dari bahan plastik PLA dengan panjang chord $(C)=100 \mathrm{~mm}$, lebar span $(\mathrm{S})=200 \mathrm{~mm}$, ketebalan maksimum $(\mathrm{t})=12 \mathrm{~mm}$, ilustrasi spesimen uji dapat dilihat dari gambar 2.proses finishing hanya dikerjakan menggunakan amplas halus untuk mencapai tingkat kekasaran. Pada bagian tengah chord diberi lubang untuk tempat peyangga ketika dilakukan pengujian pada wind tunnel.
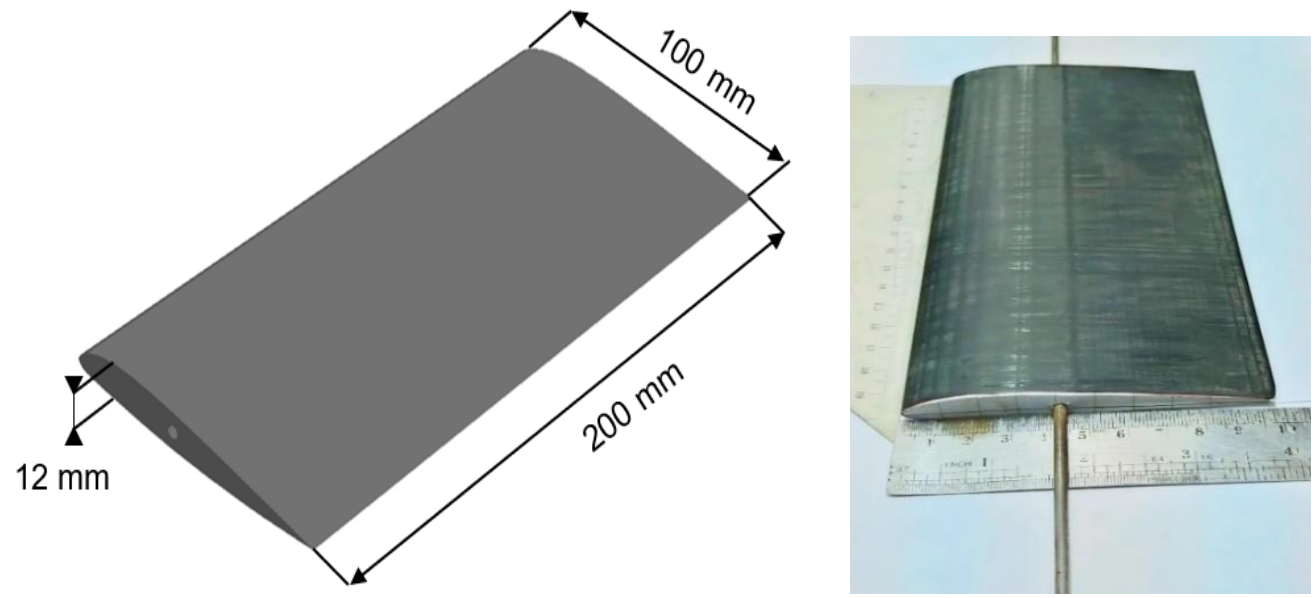

Gambar 2. Spesimen uji

Percobaan dilakukan dalam terowongan angin (subsonic wind tunnel) yang berada di laboratorium aerodinamika STTA yogyakarta. Terowongan angin memiliki dimensi test section $340 \mathrm{~mm}$ x 450 $\mathrm{mm}$ dan kecepatan maksimal mach 0.081.dalam proses pengambilan data gaya angkat dan gaya hambat kecepatan angin pada angka mach 0.081 , sudut serang diatur $(\alpha)-15^{\circ}$ hingga $20^{\circ}$. 

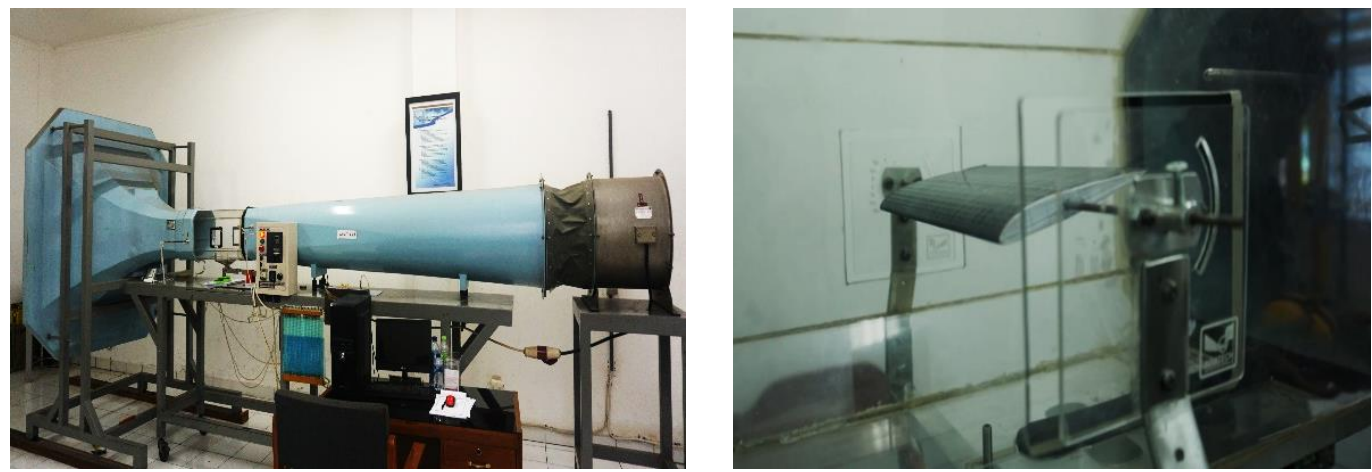

Gambar 3. Subsonic wind tunnel

\section{Simulasi}

Dengan berkembangnya penelitian yang menggunakan simulasi CFD sebagai metode untuk lebih memperpendek Distance To Reality (DTR) pada banyak kasus dalam multi-disiplin keilmuan, kemudian muncul kaidah-kaidah yang banyak dilakukan oleh para peneliti dalam memposisikan CFD dan percobaan. Dengan mengacu geometri spesimen uji pada metode eksperimen, simulasi diawali dengan pembuatan domain komputasi design mesh 2D dengan bentuk setengah lingkaran pada bagian depan dan kotak pada bagian belakangnya. Setalah melalui berbagai macam pembuatan mesh halus hingga kasar digunakan mesh dengan jumlah elemen 376500 dan jumlah node 375000. Mesh dibuat dibuat rapat disekitar dinding airfoil dan lebih longgar jauh dari dinding airfoil dengan menerapakan model turbulensi sparat-almarast dan untuk mendapatkan perubahan sudut serang sebagaimana dalam eksperimen, sudut kecepatan perlu diatur dalam pendifisian kondisi batas aliran pada saat setup dan simulasi dilakukan secara berulang untuk variasi yang dimaksud.
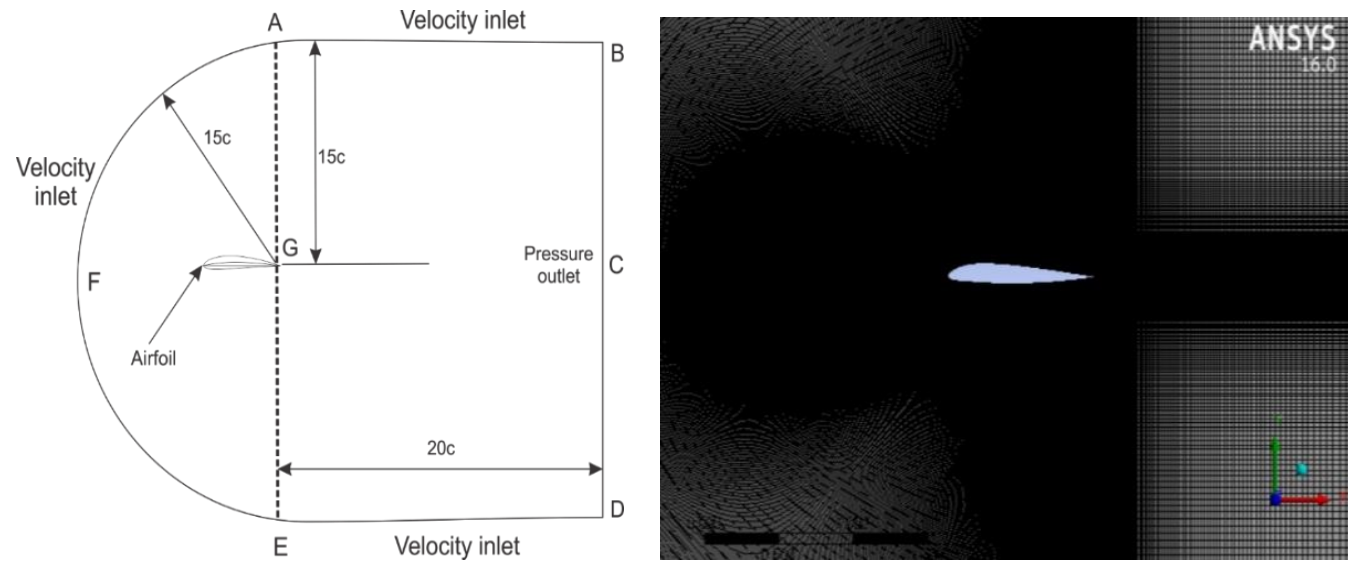

Gambar 4. Domain komputasi dan mesh 


\section{HASIL DAN DISKUSI}

Penelitian eksperimen telah menghasilkan koefisien angkat dan koefisien hambat dan untuk melengkapi karakteristik hasil dari simulasi berups koefisien hambat, koefisien angkat, visualisai kontur tekanan dan streamline. beberapa karakteristik tersebut dapat diuraikan sebagai berikut :

\section{Koefisien Lift}

Berdasarkan Gambar 5. menunjukkan nilai prediksi data $\mathrm{C}_{\mathrm{L}}$ hasil dari CFD 2D yang dibandingkan dengan data hasil eksperimen wind tunnel.dari kedua data tersebut Nilai prediksi $\mathrm{C}_{\mathrm{L}}$ ini memiliki trend yang mirip ,pada hasil CFD 2D nilai $\mathrm{C}_{\mathrm{L}}$ meningkat seiring dengan bertambah besarnya sudut serang hingga kisaran $15^{\circ}$ dan kemudian mengalami penurunan atau fenomena stall pada kisaran sudut $20^{\circ}$. Nilai $\mathrm{C}_{\mathrm{L}}$ tertinggi untuk pendekatan simulasi CFD 2D didapatkan pada kisaran sudut serang $15^{\circ}$ yaitu kecepatan $0.0809 \mathrm{M}$ sebesar 1.513275,Nilai $\mathrm{C}_{\mathrm{L}}$ hasil eksperimen wind tunnel lebih kecil dari pada hasil CFD, nilai $\mathrm{C}_{\mathrm{L}}$ tertinggi pada eksperimen wind tunnel pada kecepatan $0.0809 \mathrm{M}$ sebesar 1.291662. Pada metode eksperimen nilai $\mathrm{C}_{\mathrm{L}}$ akan terus meningkat dan tidak mengalami penurunan (fenomen stall). Hal ini mungkin disebabkan pada metode eksperimen wind tunnel saat pengambilan nilai pengkalibrasian dilakukan sekali, sehingga perlu dilakukan pengkalibrasian yang teratur untuk menjaga keakuratan pembacaan data pada timbangan force balancing mesin tidak mampu menunjukkan fenomena stall Dari hasil kedua metode tersebut koefisien angkat tertinggi terdapat pada kisaran sudut serang sebesar $15^{\circ}$.

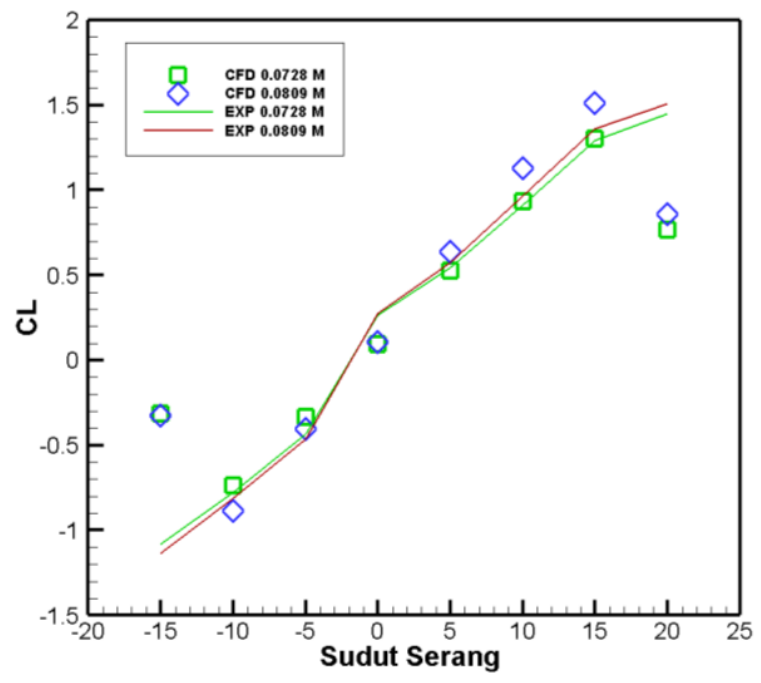

Gambar 5. Koefisien angkat

\section{Koefisien Drag}

Berdasarkan gambar 6 dapat diketahui perbandingan nilai prediksi data $C_{D}$ hasil dari simulasi CFD 2D dengan data hasil eksperimen wind tunnel dari gambar 3 nilai $C_{D}$ yang dihasilkan oleh airfoil NACA 24112 senantiasa meningkat seiring dengan meningkatnya sudut serang .Nilai prediksi $C_{D}$ hasil simulasi CFD 2D memiliki trendline yang sesuai dengan data hasil eksperimen wind tunnel, akan tetapi data $C_{D}$ hasil eksperimen wind tunnel jauh lebih besar dibandingkan dengan hasil simulasi CFD. Nilai $C_{D}$ tertinggi hasil simulasi CFD 2D pada kecepatan $0.0809 \mathrm{M}$ sebesar 0.140124 ,Nilai $C_{D}$ tertinggi hasil eksperimen wind tunnel pada kecepatan $0.0809 \mathrm{M}$ sebesar 
Vol.1, No.1, Januari 2021, pp.1-11 e-ISSN: 2774-8006 | p-ISSN: 2774-8278

0.364508. Berdasarkan hasil kedua metode koefisien hambat tertinggi terjadi pada sudut serang $15^{\circ}$.

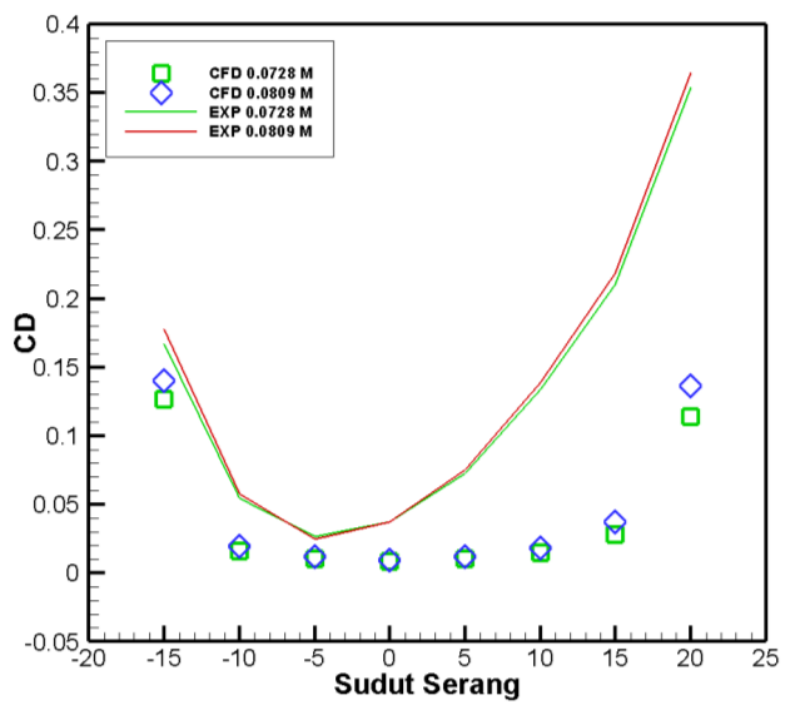

Gambar 6. Koefisien hambat

\section{Rasio L/D}

Berdasarkan gambar 7 dapat dianalisa bahwa prediksi nilai rasio $C_{L} / C_{D}$ hasil simulasi memiliki trend yang mirip dengan trend $C_{L} / C_{D}$ hasil eksperimen wind tunnel, akan tetapi nilai rasio $C_{L} / C_{D}$ hasil eksperimen jauh lebih kecil dibandingkan hasil simulasi. Hasil CFD dan eksperimen wind tunnel memiliki nilai rasio $C_{L} / C_{D}$ tertinggi terjadi pada sudut serang $10^{\circ}$ dengan rincian sebgai berikut: Hasil simulasi CFD 2D kecepatan 0.0809 M sebesar 62.06176.Setelah melebihi sudut serang $10^{\circ}$ rasio $C_{L} / C_{D}$ mengalami penurunan secara drastis. Hasil eksperimen wind tunnel nilai rasio $C_{L} / C_{D}$ tertinggi pada kecepatan $0.0809 \mathrm{M}$ sebesar 6.961482. Dan. Perbedaan rasio L/D pada kedua metode dapat disebabkan kekasaran permukaan pada airfoil yang untuk metode eksperimen masih kasar ataupun kesalahan pembacaan data. Sehingga rasio L/D maksimal pada airfoil Naca 24112 terjadi pada sudut serang antara $10^{\circ}$. 
Vol.1, No.1, Januari 2021, pp.1-11 e-ISSN: 2774-8006 | p-ISSN: 2774-8278

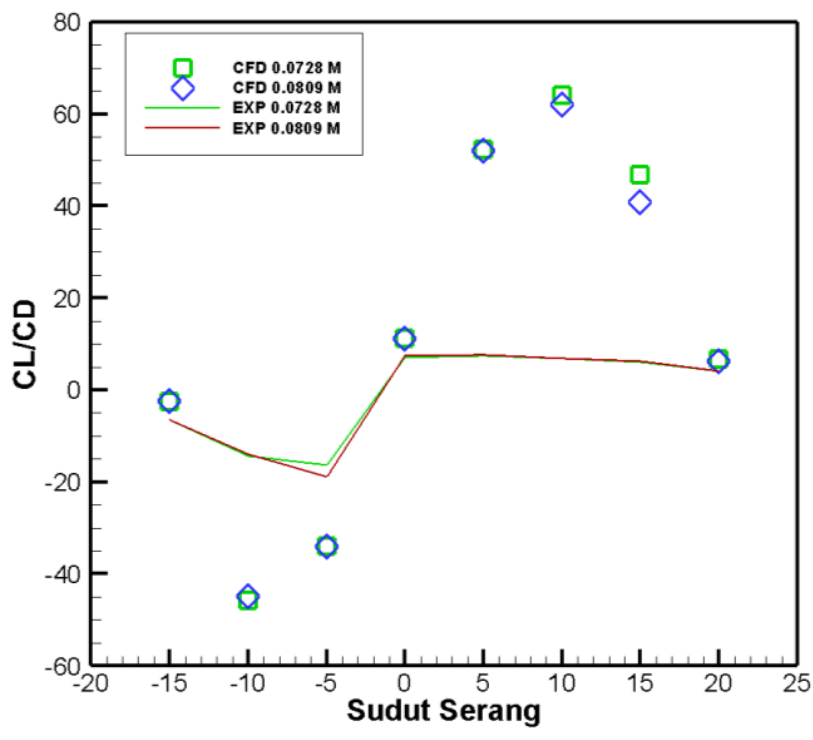

Gambar 7. Rasio $\mathrm{C}_{\mathrm{L}} / \mathrm{C}_{\mathrm{D}}$

\section{Koefisien Tekanan $\left(C_{P}\right)$}

Distribusi tekanan menentukan besarnya gaya angkat $\left(\mathrm{F}_{\mathrm{L}}\right)$, gaya hambat $\left(\mathrm{F}_{\mathrm{D}}\right)$, momen, dan posisi pusat tekanannya. Biasanya distribusi tekanan disajikan berupa nilai koefisien tekanan $\left(\mathrm{C}_{\mathrm{P}}\right)$. Pada penilitian ini distribusi nilai koefisien tekanan $\left(\mathrm{C}_{\mathrm{P}}\right)$ di sekitar airfoil didapatkan dari hasil simulasi CFD 2 dimensi, yang terbagi menjadi 2 yaitu tekanan di sepanjang permukaan bagian atas airfoil(top surface) dan tekanan di sepanjang permukaan bagian bawah airfoil(bottom surface). Grafik distribusi tekanan disekitar permukaan airfoil NACA 24112 dapat dilihat pada gambar.

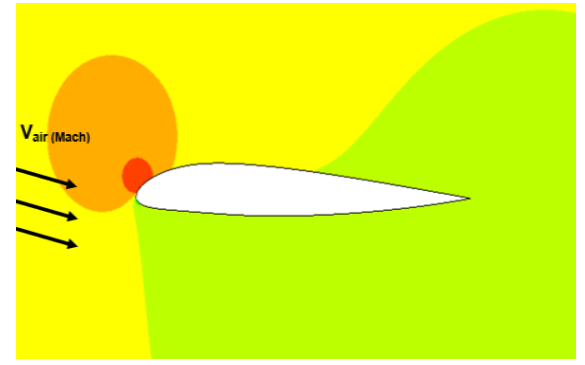

$15^{\circ}$

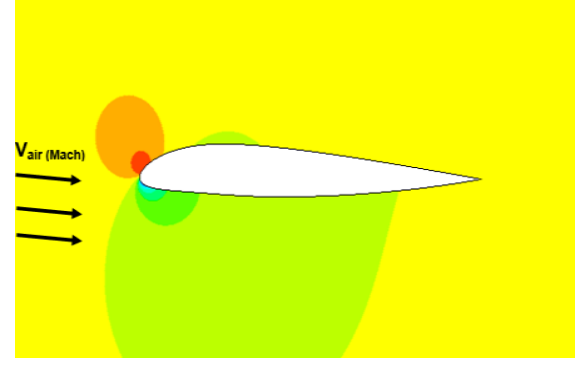

$-5^{\circ}$

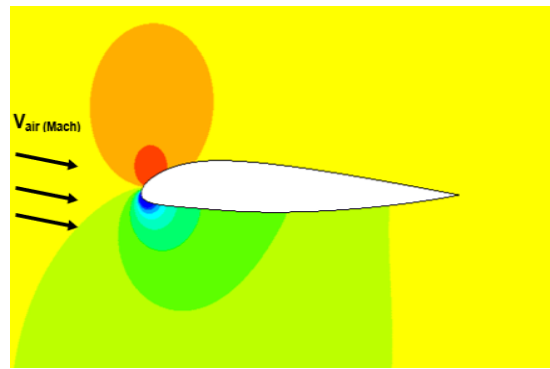

$-10^{\circ}$

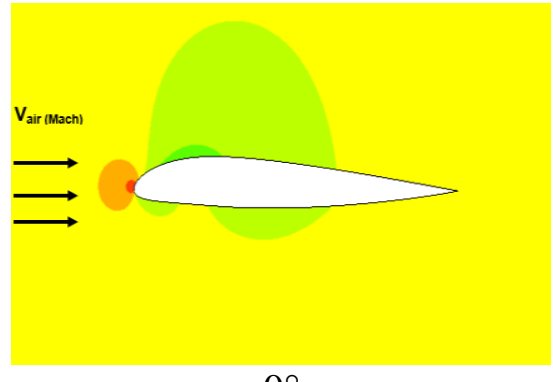

$0^{\circ}$ 
Vol.1, No.1, Januari 2021, pp.1-11 e-ISSN: 2774-8006 | p-ISSN: 2774-8278

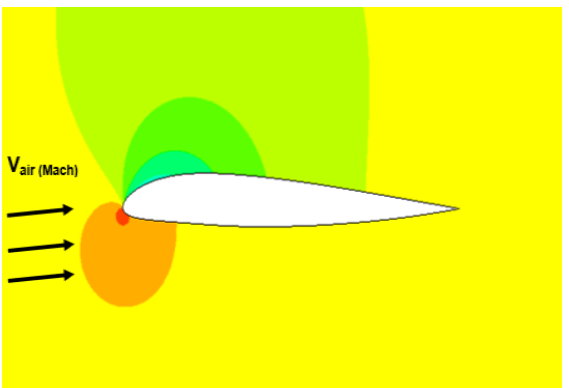

$5^{\circ}$

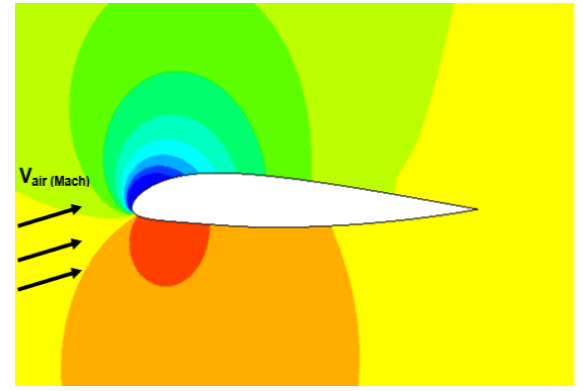

$15^{\circ}$

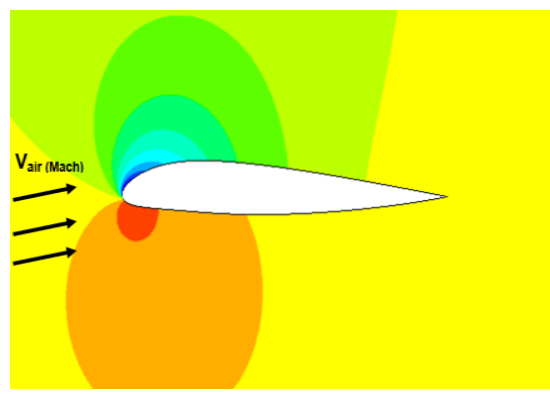

$10^{\circ}$

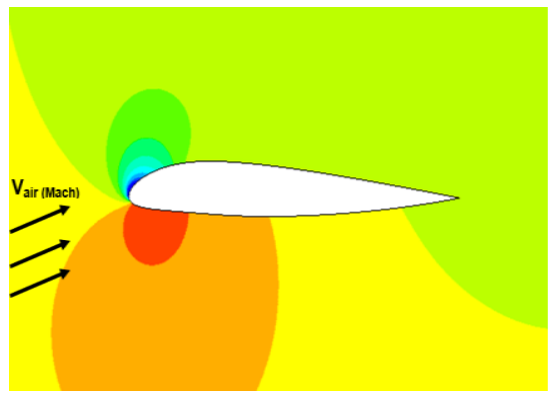

$20^{\circ}$

Gambar 8. Distribusi tekanan

\section{Profil Aliran disekitar Airfoil}

Berdasarkan gambar 9 dapat jelaskan bahwa pada kondisi sudut serang negatif $\left(-15^{\circ}\right.$ hingga $\left.-5^{\circ}\right)$ aliran dibawah airfoil lebih cepat dibandingkan aliran diatas airfoil, sedangkan pada kondisi sudut serang positif $\left(5^{\circ}\right.$ hingga $\left.15^{\circ}\right)$ aliran diatas airfoil memiliki kecepatan yang lebih tinggi dibandingkan aliran dibawah airfoil. Teramati juga pada kondisi sudut serang $20^{\circ}$ terjadi aliran yang bergerak memutar (Turbulent) dengan kecepatan rendah pada bagian atas airfoil.
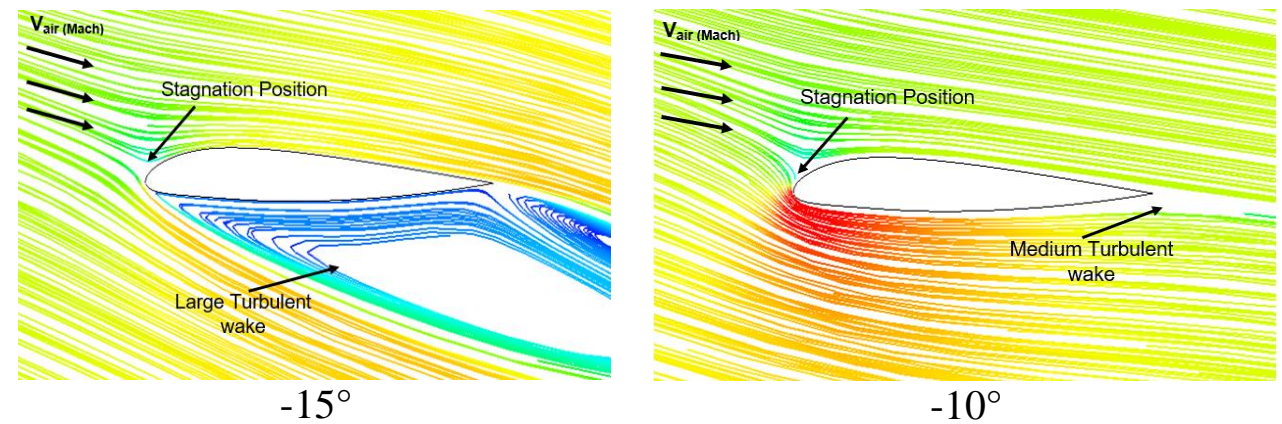
Vol.1, No.1, Januari 2021, pp.1-11 e-ISSN: 2774-8006 | p-ISSN: 2774-8278
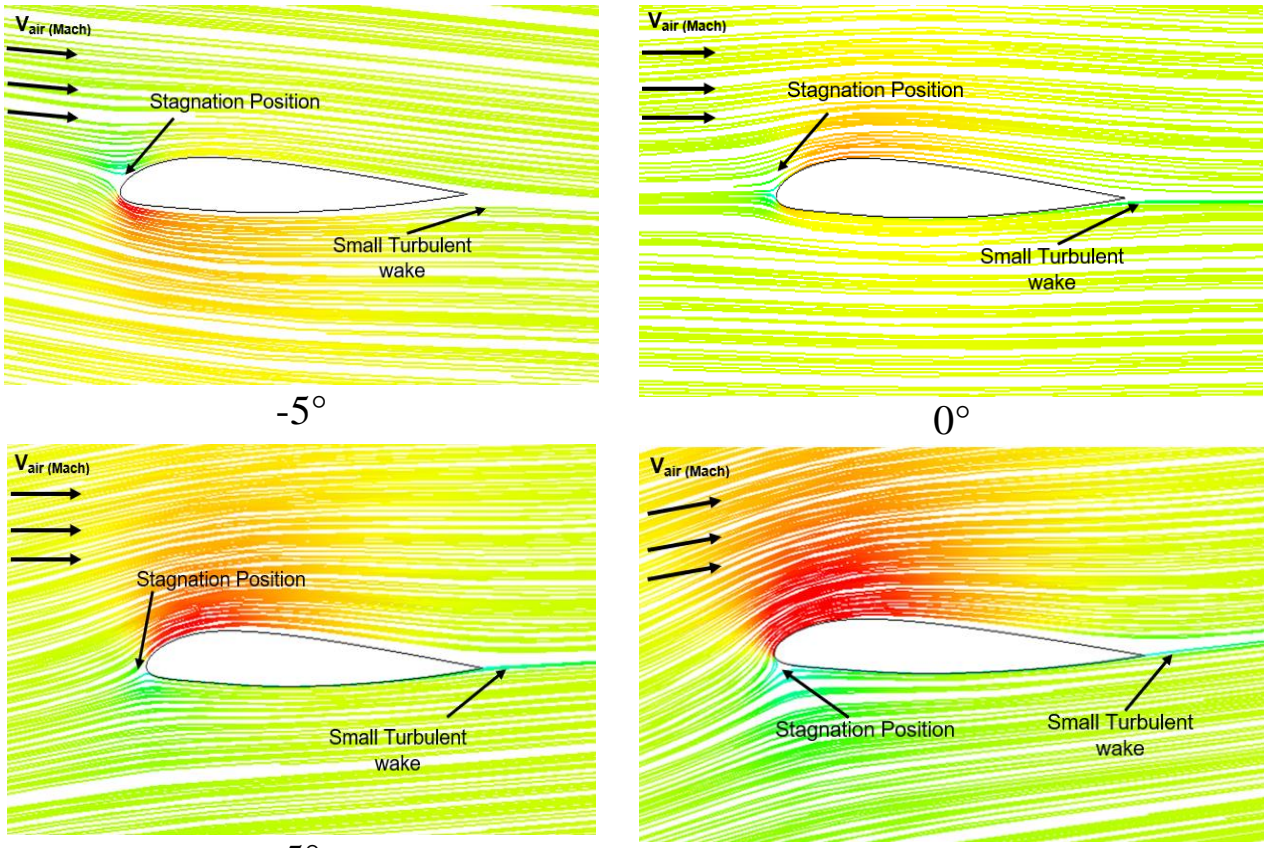

$5^{\circ}$

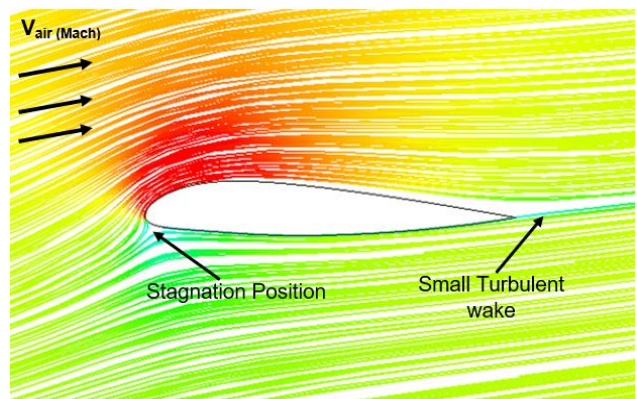

$10^{\circ}$

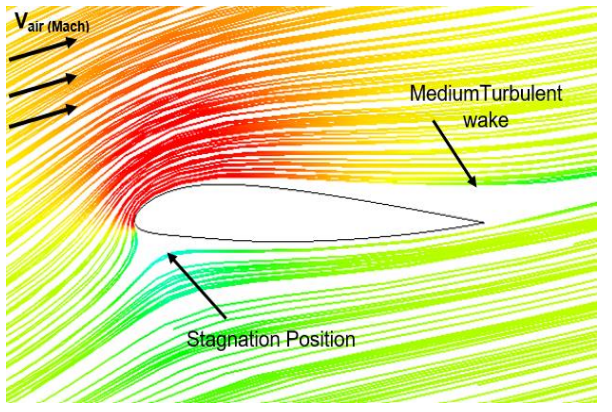

$15^{\circ}$

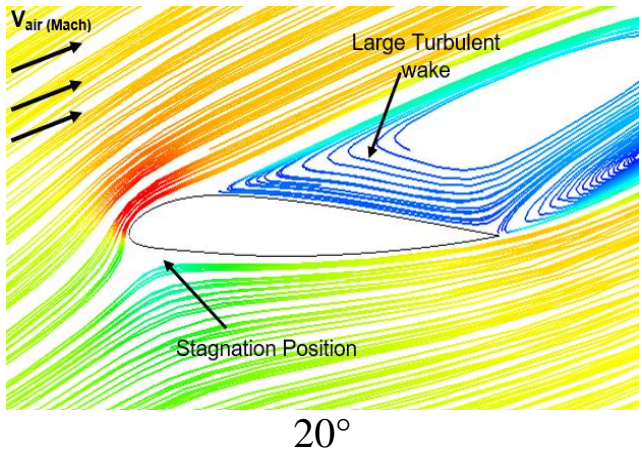

Gambar 9. Karakteristik aliran disekitar airfoil

\section{KESIMPULAN}

Berdasarkan dari analisis hasil dan pembahasan dapat ditarik kesimpulan Seiring dengan peningkatan sudut serang $(\alpha)$, nilai koefisien angkat tertinggi terjadi pada sudut $15^{\circ}$, setelah sudut serang melebihi $15^{\circ}$ nilai koefisien angkat mengalami penuruna secara signifikan, kondisi ini disebut stall. koefisien hambat juga mengalami peningkatan. Nilai koefisien hambat tertinggi pada sudut $15^{\circ}$. kontur tekanan diketahui stall pada sudut srang $20^{\circ}$ fenomena ini diketahui terjadi karena turbulensi aliran pada permukaaan atas airfoil sehingga menyebabkan nilai $\mathrm{C}_{\mathrm{L}}$ turun. Efisiensi Angkat merupakan rasio nilai lift dibandingkan dengan nilai drag. Berdasarkan hasil grafik rasio $C_{L} / C_{D}$ nilai efisiensi angkat tertinggi terdapat pada sudut serang $10^{\circ}$. Nilai presentase error koefisien lift sudah cukup baik dengan pengecualian sudut $-15^{\circ}$ dan $20^{\circ}$. Sedangakan koefisien drag nilai presentase error nya sangat besar. Penyimpangan ini kemungkinan dipengaruhi pada kedua metode, pada metode uji eksperimen saat pengambilan nilai drag pengkalibrasian dilakukan sekali, oleh karena itu seiring penggantian posisi sudut serang dan penggantian spesimen 
uji akan terjadi perubahan dari hasil kalibrasi awal sehingga perlu dilakukan pengkalibrasian yang teratur untuk menjaga keakuratan pembacaan data pada timbangan force balancing. Pada metode simulasi CFD dikarenakan kondisi batas yang dimasukkan masih belum sesuai pada kondisi eksperimen. Namun meski demikian hasil penelitian yang didapat masih dalam trend yang mirip.

\section{DAFTAR PUSTAKA}

[1] R. I. Rubel, K. Uddin, and Z. Islam, "Comparison of Aerodynamics Characteristics of NACA 0015 \& NACA 4415Aerofoil blade," no.11 October, pp. 1-10, 2016, doi: 10.20944/preprints201610.0095.v1.

[2] M. Effendy et al., "Studi Eksperimental dan Simulasi Numerik Karakteristik Aerodinamika Airfoil NACA 4412," vol. 21, no. 3, pp. 147-154, 2019.

[3] J. Yao, W. Yuan, J. Xie, and H. Zhou, "Procedia Engineering Numerical simulation of aerodynamic performance for two dimensional wind turbine airfoils," vol. 00, no. 2011, 2012, doi: 10.1016/j.proeng.2012.01.994.

[4] M. N. Haque, M. Ali, and I. Ara, "Experimental Investigation On The Performance Of NACA 4412 Aerofoil With Curved Leading Edge Planform," Procedia Eng., vol. 105, no. Icte 2014, pp. 232240, 2015, doi: 10.1016/j.proeng.2015.05.099.

[5] Q. Qu, X. Jia, W. Wang, P. Liu, and R. K. Agarwal, "Numerical study of the aerodynamics of a NACA 4412 airfoil in dynamic ground effect," Aerosp. Sci. Technol., vol. 38, pp. 56-63, 2014, doi: 10.1016/j.ast.2014.07.016.

[6] H.M.Tsabit, "Desain Prototip Drag And Lift Balance Pada Wind Tunnel Siklus Prototype For A Closed Loop," Surabaya 2017.

[7] K. S. Patel, S. B. Patel, U. B. Patel, and P. A. P. Ahuja, "CFD Analysis of an Aerofoil Angle of Attack," vol. 5013, no. 3, pp. 154-158, 2014.

[8] V. G. Pathade, K. B. Kale, and S. K. More, "CFD Analysis \& Experimental investigation of NACA0018 Blade Profile for Darrieus Turbine,” vol. 4, no. 8, pp. 1-9, 2016.

[9] O. Winter and P. Sváček, "On Numerical Simulation Of Flexibly Supported Airfoil In Interaction With Incompressible Fluid Flow Using Laminar - Turbulence Transition Model," Comput. Math. with Appl., no. xxxx, 2020, doi: 10.1016/j.camwa.2019.12.022.

[10] M.mirsal lubis, "Analisis Aerodinamika Airfoil Naca 2412 Pada Sayap Pesawat Model Tipe Model Tipe Glider dengan Software berbasis CFD,"Medan 2012.

[11] B. V. bhargav P. S. R. S.V.SA.Hema Sai Chand , K.Giridhar, T Keerthi Goud, "Transonic shockwave / boundary layer interactions on NACA 5 series -24112," pp. 629-634, 2014.

[12] V. Kumar, J. A. G. S. Saini, and R. Singh, "International Journal Of Aerospace And Mechanical Engineering Computational Fluid Dynamics Of Reflex International Journal Of Aerospace And Mechanical Engineering," vol. 2, no. 6, pp. 11-13, 2015.

[13] J. Y. Jin and M. S. Virk, "Journal of Wind Engineering \& Industrial Aerodynamics Study of ice accretion along symmetric and asymmetric airfoils," J. Wind Eng. Ind. Aerodyn., vol. 179, no. March, pp. 240-249, 2018, doi: 10.1016/j.jweia.2018.06.004.

[14] R. Azim, "Numerical Investigation on the Delay of Boundary Layer Separation by Suction for NACA 4412 ScienceDirect Numerical investigation on the delay of boundary layer separation by suction for NACA 4412,"Procedia Eng.no.329-334 October, 2015, doi: 10.1016/j.proeng.2015.05.013.

[15] G. M. J. Alam, A. Taher, and Q. Islam, "Investigation of the aerodynamic characteristics of an aerofoil shaped fuselage UAV model," Procedia Eng., vol. 90, pp. 225-231, 2014, doi: 10.1016/j.proeng.2014.11.841. 


\section{Creative Research in Engineering (CERIE) \\ Vol.1, No.1, Januari 2021, pp.1-11 e-ISSN: 2774-8006 | p-ISSN: 2774-8278}

[16] B. R.Munson, T. H. O. Donald F.Young, And Wade W.Huebsch, Elementary Fluid Dynamic The Bernouli Equation, Fundamental Fluids Mech, pp 93-146,2009.

[17] D. T. Valentine,E.L Hougthon "Aerodynamics for Engineering Students Aerodynamics sixt edition" Chapter 1 ,Airfoil Characteristic,pp 49-70,2013 